\title{
Composition and intra-annual variation of the macroinfauna in the estuarine zone of the Pando Stream (Uruguay)
}

\author{
Passadore, C.*, Giménez, L. and Acuña, A. \\ Sección Oceanología, Facultad de Ciencias, Iguá 4225, Montevideo, Uruguay \\ *e-mail: cecipass@adinet.com.uy \\ Received February 11, 2005 - Accepted May 9, 2005 - Distributed May 31, 2007
}

(With 5 figures)

\begin{abstract}
We studied the temporal patterns of macroinfaunal distribution in the estuarine portion of Pando Stream, Uruguay. We found a very low number of species and a high dominance of the polychaete Heteromastus similis. There were clear seasonal patterns in abundance with almost all species peaking in autumn, coinciding with the periods of higher salinity. Minimal values were found in winter and spring when salinity was at a minimum. We suggest that the seasonal pattern is a consequence of the combined effects of recruitment, and of high osmotic stress and disturbance during the periods of freshwater discharge that are common in winter and spring.
\end{abstract}

Keywords: estuarine benthos, seasonal patterns, Uruguay.

\section{Composição e variação intra-anual da macroinfauna da área estuarina do Arroio Pando (Uruguai)}

\begin{abstract}
Resumo
Estudamos os padrões temporais da distribuição da macroinfauna da área estuarina do Arroio Pando, Uruguai. Foi encontrado um baixo número de espécies e uma grande dominância do poliqueto Heteromastus similis. Houve claros padrões sazonais na abundância, com uma maior presença das espécies no outono, período este coincidente com valores de maior salinidade. Os valores mínimos foram encontrados no inverno e na primavera, quando a salinidade era mínima. Sugerimos que o padrão sazonal é consequiência dos efeitos misturados do recrutamento, do elevado stress osmótico e dos distúrbios durante os períodos da descarga da água doce, semelhantes no inverno e na primavera.
\end{abstract}

Palavras-chave: bentos estuarino, padrões sazonais, Uruguai.

\section{Introduction}

Benthic fauna of estuaries is characterized by a low number of species which usually reach relatively high abundance and biomass. Throughout the year, the community of benthic organisms may fluctuate cyclically due to the life cycles of the species, and temporal variations in the abiotic (e.g. salinity) and biotic (e.g. predation pressure) factors (Bemvenuti, 1988; Day et al., 1989; Levinton, 1995; Thiel and Potter, 2001). Spatial distribution of benthic fauna may be patchy due to patchiness in the characteristics of the sediments.

A great part of the Uruguayan coast belongs to the estuarine region of Río de la Plata. This is a coastal plain estuary draining the second largest basin of South America (Guerrero et al., 1997; Mianzan et al., 2001). On the Uruguayan coast, several streams and rivers are open to the estuary constituting very shallow and protected habitats as compared with the deeper and more exposed main portion of the estuary of the Río de la Plata. Recently, the necessity of an evaluation of tempo- ral changes in benthic communities has been identified as a priority in research of estuarine habitats of Uruguay (Calliari et al., 2003). The few investigations focusing on temporal variation in estuarine macrobenthos of the Uruguayan coast (e.g. Cardezo, 1989; Jorcín, 1999) had the temporal resolution of about 3 months. However, a higher temporal resolution is required to correctly evaluate the dynamics of these communities and formulate hypotheses and models that will eventually be tested.

The objective of this study is to characterize the temporal variations in the structure of the benthic community of the estuarine area of Pando Stream $\left(55^{\circ} 51.75^{\prime} \mathrm{W}\right.$ and $\left.34^{\circ} 47.75^{\prime} \mathrm{S}\right)$ with a monthly temporal resolution. This stream drains a basin of $824 \mathrm{~km}^{2}$ and is open to the estuarine area of Río de la Plata. It is affected by industrial activities and by the urban waste of the city of Pando (Amorín and Cabal, 1996). The mouth of the stream is a touristic and residential area, used as a recreational and fishing location during summer (Amorín 
and Cabal, 1996). The stream also constitutes a part of the nursery area of several commercially important fish (Richly et al., 2003).

\section{Materials and Methods}

The mouth of Pando Stream (Figure 1) is located about $30 \mathrm{~km}$ from Montevideo city. The stream has a low slope and a relatively permeable soil that affects sedimentation and water run-off (Amorín and Cabal, 1996). It receives the waters of the Tropa Vieja Stream in its final section and its mouth is connected to the Río de la Plata. Available data of salinity and temperature are restricted to autumn $\left(\mathrm{S}=5-15 ; 13-14{ }^{\circ} \mathrm{C}\right)$ and summer ( $\mathrm{S}=17-20 ; 21-23{ }^{\circ} \mathrm{C}$ ). During the last decade the mouth of the stream has been moving eastward due to the erosion on the east side and the sand deposition on the western side (Amorín and Cabal, 1996).

Samples were taken monthly between September 2002 and June 2003 (exceptions: December 2002 and May 2003, due to strong winds). Two transects were established parallel to the section of the stream, with three sampling stations in it, two located near the margins and one in the middle of the stream (Figure 1, Stn 4-9). The samples were collected with an Eckman grab with an area of $529 \mathrm{~cm}^{2}$; sediments were sieved through a mesh of $0.5 \mathrm{~mm}$; organisms were preserved in formaline $8 \%$ for determination in the laboratory.

Salinity and temperature was measured (WTW conductimeter) at 3 stations along the stream (Figure 1). In

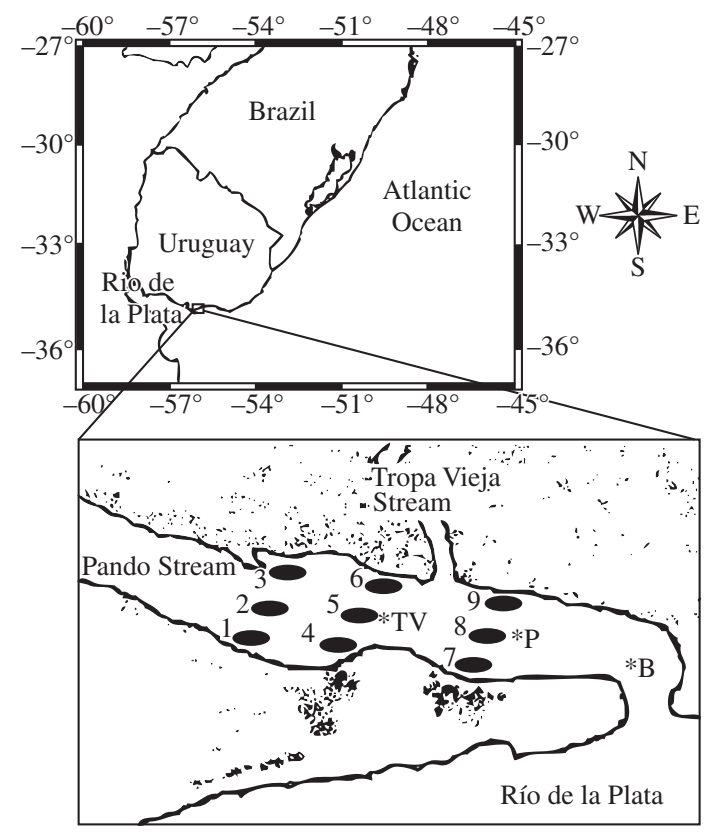

Figure 1. Study area at the mouth of Pando Stream showing sampling stations for monthly changes in abundance (Stn. 4-9), for relationships with sediment characteristics in November (additional stations 1-3), and sites for measurement of salinity and conductivity (B: Boca; P: Pescadores; e TV: Tropa Vieja).
November 2002 sediment samples were collected using a corer of $5 \mathrm{~cm}$ of diameter in the stations where biological samples were taken (Figure 1, Stn 4-9), and an additional transect for macroinfauna and sediment was sampled (Figure 1, Stn 1-3). They were used for analyses of sediment fractions: the samples were dried, weighed and the mud fraction was separated by sieving the wet sediment through a mesh of $0.63 \mu \mathrm{m}$. The remaining fraction was dried again and mechanically sieved through a series of meshes differing in 1 phi. Sediments were classified using the granulomethric classification of Wentworth (Arocena et al., 1999).

The community was characterized based on the distribution and abundance of the organisms. Principal coordinate analysis (PCO: Anderson, 2003) and cluster analysis were used on a matrix of 6 species (variables) and eight sampling occasions (objects). Data were square root transformed; the similarity matrix was calculated using the Bray-Curtis index, and UPGMA method of agglomeration (Legendre and Legendre 1998). Pearson's correlation was used to investigate if PCO axes were related to temperature and salinity. Further relationships between faunal abundance, salinity and temperature were also explored by Pearson's correlation (Ludwig et al., 1988) using the abundance data obtained on all sampling occasions. With the data from November 2002 , the relationship between the sediment characteristics and abundance of the fauna was investigated.

\section{Results}

\subsection{Environmental variables}

The temperature changed seasonally with a maximum value of $25.9{ }^{\circ} \mathrm{C}$ in February and a minimum of $12.4^{\circ} \mathrm{C}$ in June (Figure 2). The spatial variations in temperature showed no clear trend and they were low $\left(<1.7^{\circ} \mathrm{C}\right)$. Surface salinity fluctuated markedly between values $<2$ in winter and spring, and 14.6 in February (Figure 2). The bottom salinity followed the same pattern but with slightly larger values (2 in January, 30 in March). The variability among sampling stations was low $(\mathrm{S}<1)$, with the highest values towards the mouth of the stream.

Sediments were dominated by poor to moderately selected medium sand, with varying percentage of mud ( $1-23 \%)$. The proportion of mud in the sediment was low $(<5 \%)$ at the margins of the upper and lower transects, and high $(>10 \%)$ in the centre of the studied area.

\subsection{Macroinfauna}

Twelve species of benthic macroinvertebrates were found. The lowest abundance and species richness were found in September and October while the highest values occurred between February and June (Figure 3). The most frequent species were the polichaetes Heteromastus similis, Laeonereis culvieri, Nephtys fluviatilis, the clam Erodona mactroides and the snail Heleobia australis (Table 1), comprising $94 \%$ of the total macrofaunal abun- 
Table 1. Frequency of monthly occurrence and relative abundance of macrobenthic species of Pando Stream, between September 2002 and June 2003.

\begin{tabular}{lcc}
\hline \multicolumn{1}{c}{ Taxon and Species } & Monthly occurrence (\%) & Relative abundance \\
\hline ANNELIDA, POLYCHAETA & & \\
Heteromastus similis & 100 & 20.33 \\
Laeonereis culvieri & 87.5 & 22.65 \\
Nephtys fluviatilis & 62.5 & 2.20 \\
$\quad$ Unidentified polychaete & 12.5 & 0.05 \\
MOLLUSCA & & \\
Erodona mactroides & 100 & 21.29 \\
Heleobia australis & 50 & 27.62 \\
Brachidontes darwinianus & 37.5 & 0.28 \\
Tagelus plebeius & 12.5 & 0.05 \\
CRUSTACEA & & \\
Cyrtograpsus angulatus & 12.5 & 0.05 \\
Excirolana sp. & 12.5 & 0.05 \\
Unidentified ostracods & 12.5 & 5.36 \\
INSECTA & & \\
Ephemeroptera larvae & 12.5 & 0.05 \\
\hline
\end{tabular}
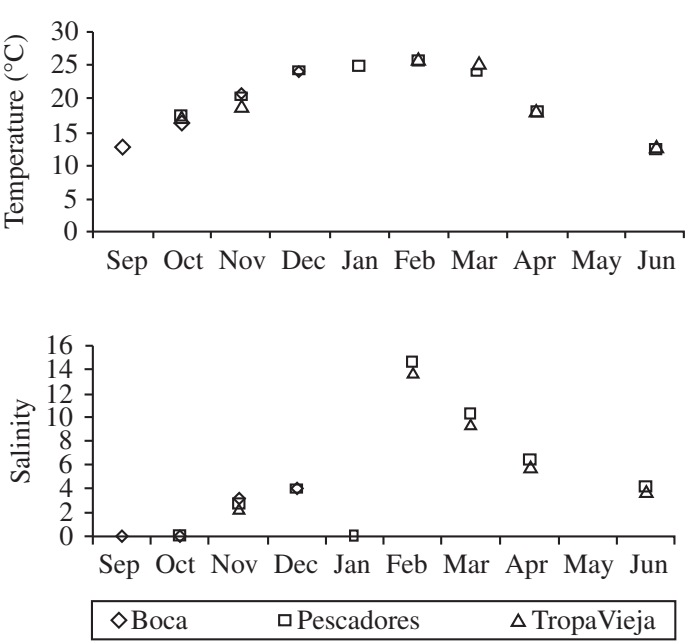

Figure 2. Surface water temperature and salinity, at Pando Stream between September 2002 and June 2003.

dance. In June high numbers of an unidentified ostracod were found (89 ind. at Stn 7). We also found Balanus improvisus settled on wood and shells of E. mactroides, but it was not further considered.

Principal coordinate (PCO) and cluster analyses aggregated the sampling occasions in three groups: 1) September-October; 2) November-January; and 3) February-June (Figure 4). Group 1 indicates low abundances in September and October for all species but $H$. similis and E. mactroides; group 2 high abundances of $E$. mactroides in November-January; group 3 high abundance of most species between February and June (Figure 3). The species abundance peaked in different months (Figure 3). For E. mactroides, the peak of abundance occurred in November, when $98 \%$ of the
170 individuals collected ranged from 18 to $34 \mathrm{~mm}$; although small individuals were found on all sampling occasions, the highest abundance was observed in January, when $28 \%$ of the 43 individuals collected ranged from 2 to $14 \mathrm{~mm}$.

The first axis of the PCO was significantly correlated with salinity (Figure 5) but not with temperature ( $\mathrm{p}>0.05$ ). The abundance of $H$. similis and L. culvieri were significantly and positively correlated with salinity, but only for L. culvieri was the correlation with temperature significant (Table 2).

For the nine stations sampled in November, only the abundance of $H$. similis showed a significant correlation $(\mathrm{r}=0.670, \mathrm{p}<0.05)$ with the percentage of mud of the sediment; the correlations between the mud content and E. mactroides $(\mathrm{r}=0.478)$, and L. culvieri $(\mathrm{r}=-0.383)$ were not significant.

\section{Discussion}

\subsection{Environmental variables}

Temperature and salinity showed a clear seasonal pattern at the mouth of Pando Stream, with a winter characterized by cold freshwater and a summer dominated by warm estuarine water. As expected for a temperate region, temperatures were highest at the end of the summer while the lowest values were reached at the end of winter. This is consistent with the patterns described for the South Atlantic estuaries such as the Río de la Plata (Nagy et al., 1997) and Patos Lagoon (Chao et al., 1985). The temporal patterns of salinity at Pando Stream are most likely affected by patterns of rainfall occurring on its basin and by changes in the position of the salinity front of Río de la Plata. Thus, decreases in salinity in Pando Stream should occur through increased freshwater 
Heteromastus similis
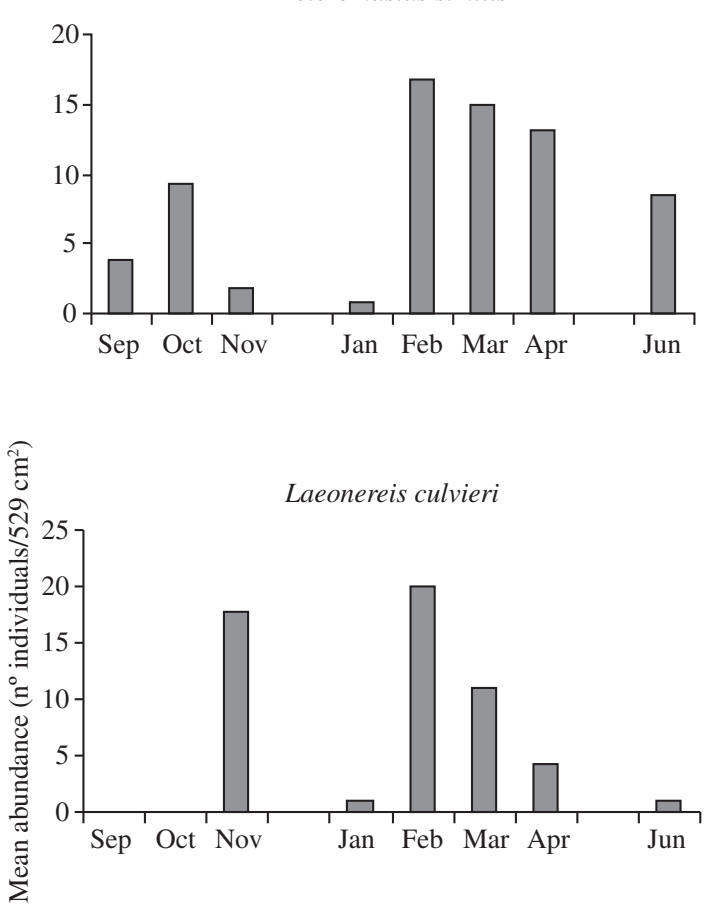

Nephtys fluviatilis

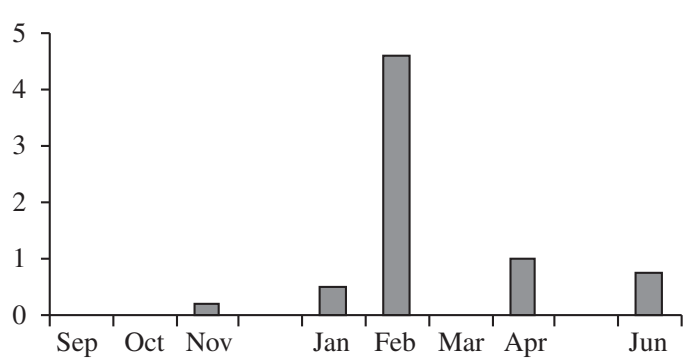

Erodona mactroides


Brachidontes darwinianus

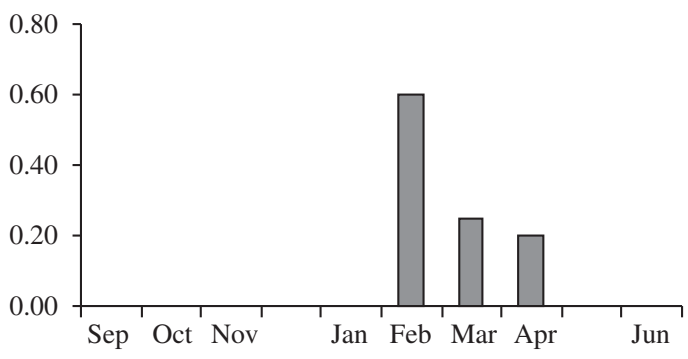

Figure 3. Mean monthly abundance of the main macroinfauna species found at six stations at Pando Stream.

Table 2. Relationship between mean monthly abundance of the main macroinfauna species at five stations, and temperature and salinity at Pando Stream. Significant correlations $(\mathrm{p}<0.05)$ are shown in bold type.

\begin{tabular}{lcc}
\hline & Temperature & Salinity \\
\hline Heteromastus similis & 0.172 & $\mathbf{0 . 4 7 9}$ \\
Erodona mactroides & 0.049 & 0.230 \\
Laenereis culvieri & $\mathbf{0 . 5 1 9}$ & $\mathbf{0 . 5 6 2}$ \\
Heleobia australis & 0.052 & 0.281 \\
\hline
\end{tabular}

discharge from up-river, but also from Río de la Plata. The low salinities registered in January were related to heavy rainfall occurring a few days before our sampling excursion.

\subsection{Macroinfauna}

The benthic community at the mouth of Pando Stream was characterized by a low species richness and by high abundance of polychaetes (mainly Heteromastus similis), which is characteristic of the estuarine areas of the South Atlantic region (Bemvenuti et al., 1978; Capitoli et al., 1978; Ieno and Bastida, 1998; Muniz and Venturini, 2001; Danulat et al., 2002).

The patterns of species abundance may result from the interaction of their specific patterns of recruitment and mortality. In temperate latitudes, seasonal patterns of reproduction cause pulses due to incorporation of recruits and subsequent mortality (Boesch, 1977; Holland 

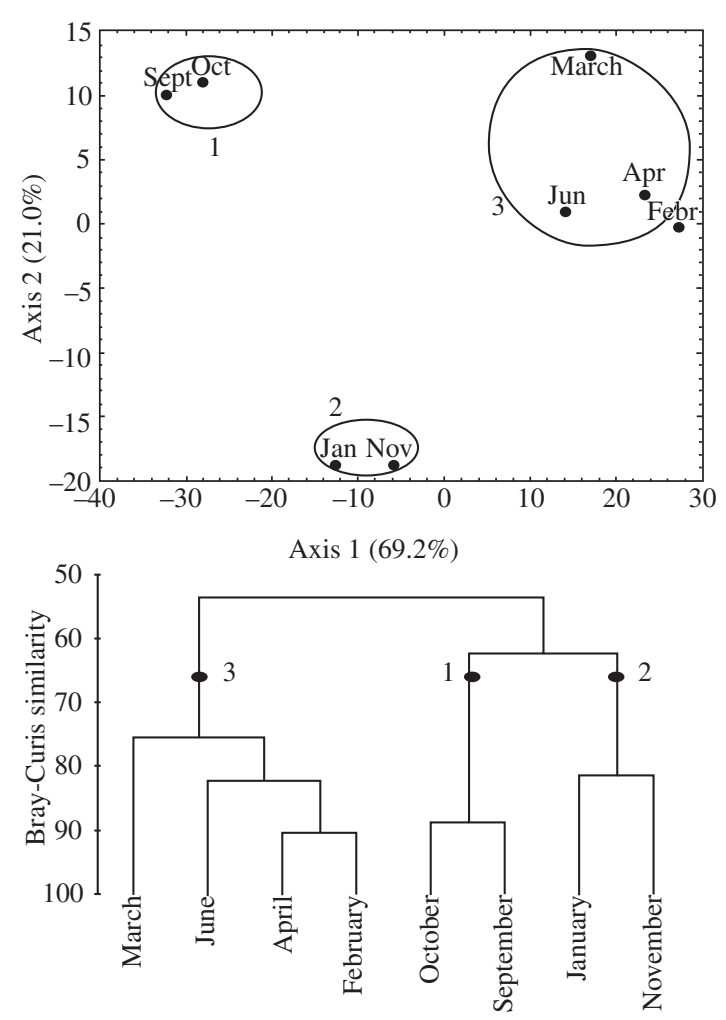

Figure 4. Principal coordinate analysis (PCO) and cluster analysis of mean abundance of macroinfauna at the mouth of Pando Stream after root-root transformation and BrayCurtis similarity index. For PCO, the percentage explained by each axis is given in parenthesis.

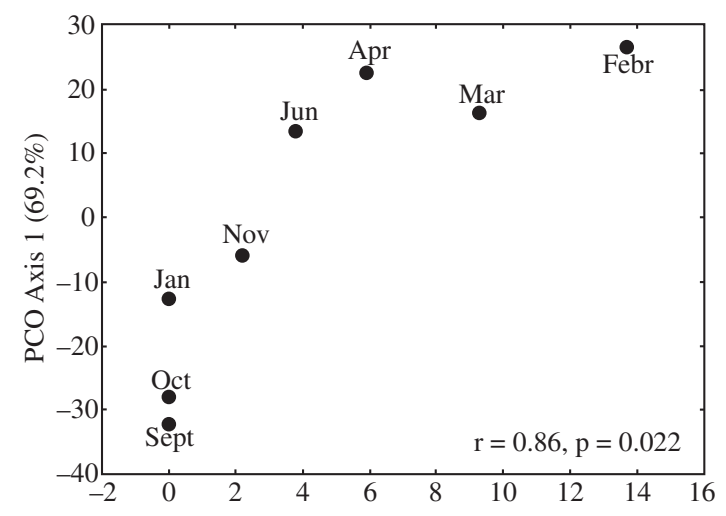

Figure 5. Relationship between the coordinates of mean monthly abundance of macroinfauna and salinity recorded at the mouth of Pando Stream.

et al., 1987). This seemed to be the case for most species found in Pando Stream, which showed a seasonal pattern of abundance. Predation, osmotic stress or disturbance by storms, droughts and sediment anoxia seem to be the main causes of mortality of estuarine benthic invertebrates (Holland et al, 1987; Day et al., 1989; Levinton, 1995; Rundle et al., 1998). For Pando Stream the low depth $(<2 \mathrm{~m})$ should preclude the occurrence of anoxic conditions, but disturbance through increased freshwater flow or predation by fish and epibenthic crabs should not be discarded as a source of mortality or emigration.

For Pando Stream the combined effect of osmotic stress and disturbance should explain the low number of species between September and January. River runoff should affect mainly epibenthic species such as Heleobia australis, and errant polychaetes such as Nephtys fluviatilis as in the case of Valizas Stream (Jorcín, 1999). Predation by fish (Micropogonias furnieri) and crabs (Callinectes sapidus, Cyrtograpsus angulatus), mainly in spring and summer, may further reduce macrofaunal abundance. From February to June, the mouth of Pando Stream was characterized by brackish water, coinciding with the peaks of abundance of almost all species (exception: E. mactroides). Brackish water entering through the mouth and the high temperature in late summer and early autumn may facilitate the recovery of populations: while high temperature should increase growth and reproduction, brackish water from the open coast should reduce osmotic stress, allow retention of individuals within the stream, and increase immigration of benthic and pelagic (larval) stages from the Río de la Plata. The presence of the brown mussel Brachidontes darwinianus, a highly abundant species in the exposed coast of the Río de la Plata estuary, should be explained by the transport of larvae from the open coast.

The exception to the process described above may occur for Heteromastus similis and Erodona mactroides. Jorcín (1999) speculated that the burrowing capacity of these two species made them less susceptible to be washed out by currents. $H$. similis burrows up to a depth of $15 \mathrm{~cm}$ in the sediment, avoiding epibenthic predation (Bemvenuti, 1988) and perhaps erosion. However, another burrower, L. culvieri, should have followed the same pattern as $E$. mactroides and $H$ similis. $H$. similis appears to recruit all year round as evidenced by the presence of juveniles in all months (Ieno \& Bastida, 1998), perhaps being able to rapidly recover from disturbance caused by freshwater flow or predation. For E. mactroides, recruitment can be discarded as an explanation for the peak of abundance in November, because almost all individuals collected in that month ranged from 18 to $34 \mathrm{~mm}$; and recruits $(<14 \mathrm{~mm})$ appeared in January when the abundance was low. $E$. mactroides is actually a surface burrower (Bemvenuti et al., 1978), a fact that may increase the susceptibility to be transported by currents. The only explanation we can offer for the peak in abundance in November is that large individuals must have been transported from the head of the river to the sampled area, while small individuals might have been transported further to the open coast.

Acknowledgments - We would like to thank Federico Viana, Agustín Carnikian, Bibiana Musso, Ruben Canavese, Julio Richly, Matías Sarucki, Fabián Vásquez, Nathalie Borba and Héctor Ferrando for their collaboration in the field; Ana Inés Borthagaray, Alvar Carranza and Marcel Rodríguez helped us in the laboratory. We also acknowledge help from the fishermen of the Pando Stream, Carlos and Eduardo, for all their generosity, and from the staff of Sección Oceanología, Facultad de Ciencias. 


\section{References}

AMORÍN, C. and CABAL, C., 1996. Informe de calidad del agua del Arroyo Pando. APRAPANDO. Universidad de la República. Facultad de Ingeniería. Montevideo, Uruguay. 48p.

ANDERSON, M., 2003. PCO: a FORTRAN computer program for principal coordinate analysis. Department of Statistics, University of Auckland, New Zealand.

AROCENA, R. and CONDE, D., 1999. Métodos en Ecología de Aguas Continentales, con Ejemplos de Limnología en Uruguay. Universidad de la República. Facultad de Ciencias. Publicaciones y Difusión (DIRAC). ISBN: 9974-0-0107-2, Montevideo, Uruguay, 233p.

BEMVENUTI, CE., CAPITOLI, RR. and GIANUCA, NM., 1978. Estudos de ecología bentônica na região estuarial da lagoa dos Patos. II- Distribução quantitativa do macrobentos infralitoral. Atlântica, Río Grande, vol. 3, p. 23-32.

BEMVENUTI, CE., 1988. Impacto da predação sobre Heteromastus similis southern, 1921 e Nephtys fluviatilis Monro, 1937 (Annelida, polychaeta), em fundos moles estuarinos. Atlântica, Río Grande, vol. 10, no. 1, p. 85-102.

BOESCH, D., 1977. A new look at the zonation of benthos along the estuarine gradient. In COULD, B. (ed.). Ecology of Marine Benthos. Library of Marine Science. vol. 6, p. 245-266. Columbia: University of South Carolina Press.

CALLIARI, D., DEFEO, O., CERVETTO, G., GÓMEZ, M., GIMÉNEZ, L., SCARABINO, F., BRAZEIRO, A. and NORBIS, W., 2003. Marine Life of Uruguay: critical update and priorities for future research.Chile, Gayana, vol. 67, n. 2, p. 341-370.

CAPITOLI, RC., BEMVENUTI, CE. and GIANUCA, NM., 1978. Estudos de ecología bentônica na região estuarial da lagoa dos Patos. I- As comunidades bentônicas. Atlântica, Río Grande, vol. 3, p. 5-22.

CARDEZO, M., 1989. Caracterización de la fauna macrobentónica de la laguna de Rocha (Uruguay). Universidad de la República. Facultad de Ciencias. Tesis Licenciatura en Oceanografía Uruguay, 95p.

CHAO, LN., PEREIRA, LE. and VIEIRA, JP., 1985. Estuarine fish community of the dos Patos Lagoon, Brasil. A baseline study. Chap. vol. 20, p. 429-450. En Fish Community ecology in Estuaries and Coastal Lagoons: Towards an Ecosystem Integration. A. Yáñez-Arancibia (Ed.). DR (R) UNAM Press México, 654p.

DANULAT, E., MUNIZ, P., GARCÍA-ALONSO, J. and YANNICELLI, B., 2002. First assessment of the highly contaminated harbour of Montevideo, Uruguay. Mar. Pollut. Bull., vol. 44, no. 6, p. 554-565.

DAY., JW., HALL, Ch. AS., KEMP, WM. and YÁNEZARANCIBIA, A., 1989. Estuarine Ecology. Wiley J. \& Sons, New York, 558p.
GUERRERO, R., ACHA, E., FRAMIÑAN, M. and LASTA, C., 1997. Physical oceanography of the Río de la Plata Estuary, Argentina. Cont. Shelf Research, vol. 17, no. 7, p. 727-742.

HOLLAND, A., SHAUGHNESSY, A. and HIEGEL, M., 1987. Long-term variation in mesohaline Chesapeake Bay macrobenthos: Spatial and temporal patterns. Estuaries, vol. 10, no. 3, p. 227-245.

IENO, E. and BASTIDA, R., 1998. Spatial and Temporal Patterns in Coastal Macrobenthos of Samborombon Bay, Argentina: A Case Study of Very Low Diversity. Estuaries, vol. 21 , no. 4 , p. $690-699$.

JORCIN, A., 1999. Temporal and spatial variability in the macrozoobenthic community along a salinity gradient in the Castillos Lagoon (Uruguay). Arch. Hydrobiol., vol. 146, no. 3, p. 369-384.

LEGEDRE, P. and LEGENDRE, L., 1998. Numerical Ecology. Elsevier Ámsterdam.

LEVINTON, JS., 1995. Marine Biology. Function, biodiversity, ecology. New York, Oxford University Press.

LUDWIG, JA. and REYNOLDS, JF., 1988. Statistical Ecology. A Primer on Methods and Computing. Wiley-interscience publication, United States, 337p.

MIANZAN, H., LASTA, C., ACHA, E., GUERRERO, R., MACCHI, G. and BREMEC, C., 2001. The Río de la Plata Estuary, Argentina-Uruguay. In SEELIGER, U., KJERFVE, B. (eds) Coastal Marine Ecosystems of Latin America. SpringerVerlag, Berlin.

MUNIZ, P. and VENTURINI, N., 2001. Spatial distribution of the macrozoobenthos in the Solís Grande Stream estuary (Canelones-Maldonado, Uruguay). Braz. Jour. of Biol., vol. 61, no. 3, p. 409-420.

NAGY, GJ., MARTÍNEZ, CM., CAFFERA, RM., PEDROSA, G., FORBES, EA., PERDOMO, AC. and LÓPEZ LABORDE, J., 1997. Marco hidrológico y climático del Río de la Plata. Cap 2:17-70. En WELLS, PG. and DABRON, GR (eds.), 1998. El Río de la Plata. Una Revisión Ambiental. Un Informe de Antecedentes del Proyecto EcoPlata. Dalhousie University, Halifax, Nova Scotia, Canada, 256p.

RICHLY, J., PASSADORE, C., FERRANDO, H., ACUÑA, A. and VIANA, F., 2003. Ictiofauna de la región estuarial del Arroyo Pando, Uruguay. Act. VII Jorn. Zool. Uruguay, 117p.

RUNDLE, S., ATTRILL, M. and ARSHAD, A., 1998. Seasonality in macroinvertebrate community composition across a neglected ecological boundary, the freshwater-estuarine transition zone. Aquat. Ecol., vol. 32, no. 3, p. 211-216.

THIEL, R. and POTTER, IC., 2001. The ichtyofaunal composition of the Elbe Estuary: an analysis in space and time. Mar. Biol., vol. 138, no. 3, p. 603-616. 